\title{
AMAZÔNIA ENCANTADA: ÉTICA AMBIENTAL E IDENTIDADE CULTURAL
}

-SCOTT WILLIAM HOEFLE

\section{RESUMO}

O RELACIONAMENTO ENTRE ÉtNICA AMBIENTAL E SISTEMA AgRícOLA É ANALISADA NA AMAZÔNIA CENTRAL E OCIDENTAL COM $O$ INTUITO DE AVALIAR INTERPRETAÇ̃̃ES DO ESTRUTURALISMO ECONÔMICO, DO MARXISMO, DA ECOLOGIA ESPIRITUAL E dA ECOLOGIA POLÍtICA. VISÕES ENCANTADAS dA NATUREZA SÃO COMUNS ENTRE A POPULAÇÃO TRADICIONAL dA AMAZÔNIA E REFLETEM SÉCULOS DE FUSÃO ÉTNICO-CULTURAL AMERÍNDIA E EUROPÉIA. UMA RICA TRADIC̦ÃO EXISTE SOBRE ENTIDADES ESPIRITUAIS DA FLORESTA E DOS RIOS POSSIBILITANDO DISCUTIR A TESE CENTRAL DA ECOLOGIA ESPIRITUAL QUE SUSTENTA QUE RELAÇÕES RECíPROCAS ENTRE ESPÍRITOS E HUMANOS FUNDAMENTADAS NUMA VISÃO VITALISTA DA NATUREZA REPRESENTAM UM ESCUDO IDEOLÓGICO EVITANDO 0 DESFLORESTAMENTO E A DESIGUALDADE SOCIAL PROVOCADO PELA AGRICULTURA MODERNA. POSIC̦̃̃ES MARXISTAS E ESTRUTURALISTAS, POR SUA VEZ, CONSIDERAM VISÕES ENCANTAdAS dO MUNDO COMO MERO EPI-FENÔMENO QUE É FATALMENTE ELIMINAdO PELO PROCESSO dE CAPITALIZAÇÃO/MODERNIZAÇÃO RURAL A MANEIRA QUE OS FENÔMENOS NATURAIS SÃO CONTROLADOS PELA TECNOLOGIA.

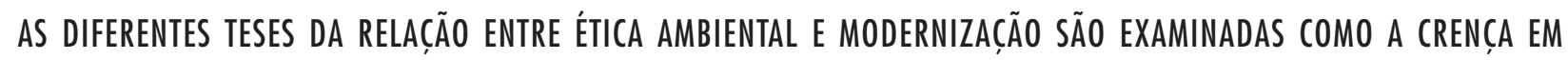
ESPíRITOS DA FLORESTA E dOS RIOS E NO VITALISMO DA NATUREZA, 0 GRAU DE DOMEStiCAÇÃO DA PAISAGEM E AS TENDÊNCIAS DE EQUIDADE SOCIAL VARIAM DE ACORDO COM O SISTEMA AGRÍCOLA PRATICADO POR COLONOS, RIBEIRINHOS E AMERÍNDIOS. CONCLUI-SE QUE A ABORDAGEM HOLÍSTICA DA ECOLOGIA POLÍTICA EXPLICA MELHOR O RELACIONAMENTO ENTRE ÉtNICA AMBIENTAL E tRANSFORMAÇÃO RURAL DO QUE INTERPRETAÇÕES DETERMINISTAS DE BASE TECNOLÓGICA OU IDEOLÓGICA SOBRE 0 PAPEL DA MODERNIZAC̦ÃO AGRÍCOLA NO DESENCANTAMENTO DA VISÃO DO MUNDO. PALAVRAS CHAVES: ÉtICA AMBIENTAL, PAISAGEM CULTURAL, AMAZÔNIA.

Além da Visão Dualista da ConsciênCia Coletiva

Tradicional e Moderna

- relacionamento entre identidade cultural, modernização rural e ética ambiental é analisada na Amazônia Central e Ocidental com o intuito de avaliar interpretações do estruturalismo e darwinismo econômico, do marxismo, da ecolo- gia espiritual e da ecologia política. Visões encantadas da Natureza são comuns entre a população tradicional da Amazônia e refletem séculos de fusão étnicocultural ameríndia e européia. Uma rica tradição existe sobre entidades espirituais da floresta e dos rios possibilitando discutir a tese central da ecologia espiritual que sustenta que as 
relações recíprocas entre espíritos e humanos decorrentes de uma visão animista e vitalista da $\mathrm{Na}$ tureza representam um escudo ideológico evitando o desflorestamento e a desigualdade social provocados pela agricultura moderna.

Ao mesmo tempo, pelo sul, chega a grande fronteira de expansão agrícola na Amazônia Central e Ocidental, trazendo produtores de outras regiões do país que podem praticar a agricultura comercial moderna, ter níveis de escolaridade mais elevados e ser protestantes ou mesmo acreditar em cosmologia materialista científica, muito aquém da cosmologia encantada do catolicismo popular dos ribeirinhos. Essa transformação, por sua vez, chama atenção a posições darwinistas, estruturalistas e marxistas, nas quais visões encantadas do mundo são consideradas meras crendices, epifenômenos, que são fatalmente eliminadas pelo processo de capitalização rural. Uma vez que o controle técnico dos fenômenos naturais diminui risco ambiental são superadas explicações tradicionais à base de agentes sobrenaturais.

Contudo, na área de estudo, nem todos os produtores localizados ao longo das rodovias utilizam tecnologia moderna e vários deles têm origem ribeirinha de forma que mesclam visões de mundo, existindo vários graus de crença e descrença em entes encantados. Assim sendo, uma abordagem dualista que foca apenas as situações uma abordagem dualista que foca apenas as situações extremas - o ribeirinho tradicional versus o produtor moderno de commodities - ignora a complexidade socioambiental presente na Amazônia e aponta conclusões simplistas, senão equivocadas, sobre a relação entre modernização e ética ambiental (indicadas com marca de interrogação na Tabela 1).

\section{TABELA 1 - A VISÃO DUALISTA DO DETERMINISMO TECNO-ECONÔMICO}

\begin{tabular}{|l|l|}
\hline \multicolumn{1}{|c|}{ Agricultura Tradicional } & \multicolumn{1}{c|}{ Agricultura Moderna } \\
\hline População ribeirinha & Imigrantes sulistas \\
\hline Agricultura de queimada de subsistência (?) & Agricultura moderna de "commodities" \\
\hline Desmatamento limitado & Desmatamento extensivo \\
\hline Contato com áreas florestadas & Substituição da flora e fauna \\
\hline $\begin{array}{l}\text { Pouco domínio de processos naturais -> risco } \\
\text { ambiental (?) }\end{array}$ & $\begin{array}{l}\text { Controle técnico da Natureza -> supera risco } \\
\text { ambiental (?) }\end{array}$ \\
\hline Baixa escolaridade & Alta escolaridade \\
\hline Catolicismo popular encantado (?) & Protestantismo desencantado (qual?) \\
\hline Natureza animada-vitalista & Natureza e religião secularizada (?) \\
\hline
\end{tabular}

Por outro lado, o presente estudo também vida a superar a abordagem folclórica com base etrnográfica, na qual o pesquisador "coleta" contos entre um número restrito de informantes, contruindo o conto "típico" supostamente presente na "consciência coletiva" da população, mas não necessariamente presente na sua totalidade na mente de indivíduos específicos. Este procedimento é duramente criticado tanto pela corrente interpretativa pós-modernista (Geertz 1973, Clifford 1986) quanto pela corrente epidemiológica neo-darwinista (Sperber 1996), por destilar o tal 
conto típico, estabelecendo o que as diferentes variantes têm em comum, preenchendo as "lacunas" e omitindo contradições e complexidade.

Assim sendo, o presente estudo explora como uma abordagem regional, baseada numa metodologia qualitativa sistemática, pode abrange a variação socioespacial, vista pela diferenciação em lugar de origem, sistema produtivo utilizado, nível de escolaridade, faixa etária, gênero e afiliação religiosa, elaborando um modelo complexo do processo de desencanbtamento da ética ambiental na Amazônia, muito aquém do determinismo tecnológico e do determinismo ideológico.

\section{Modelos de Desencantamento de Visão do}

\section{MUNDO}

Existem dois modelos opostos para explicar a relação entre transformação social e ética ambiental: 1) o do Estruturalismo Econômico, Neo-Marxista, e Neo-Darwinismo Econômico e 2) o da Ecologia Espiritual (Figura 1). Ambos modelos são deterministas, o primeiro privilegiando a inovação tecno-econômica como causa única da transfomação ambiental e social e o segundo destacando a importância de mudanças ideológicas que promovem a secularização da visão de mundo perante a Natureza.

O modelo que privilegia a modernização técnica se inspira na literatura clássica marxista e em uma vertente do pensamento weberiano da teoria de organização econômica e social. A transfomação de áreas naturais florestadas em espaços agrários e urbanos produtivos é vista como um processo de desenvolvimento da exploração dos recursos naturais A desigualdade social ocorre em função do surgimento de uma classe inovadora, de- tentora dos recursos produtivos da terra, capital e conhecimento técnico. Nesse caso, a secularização ideológica envolve a substituição de religião e outras visões do mundo fundamentadas em agentes espirituais pela visão científica com base em fatores materiais e técnicos que permite o controle e domínio da Natureza (Aron 1981, Foster 1972 (1964), Hunter (1969), Marx 1952 (1869), Weber 1964 (1919-20)).

A Ecologia Espiritual se inspira em outra vertente do pesamento weberiano: a da ética protestante (Weber, 1970 (1904-5). Sucessivas reformas religiosas, e finalmente, o surgimento da Ciência, materialista e quantitativa, promoveram o desencantamento ideológico que, em primeiro lugar, elimina a crença nos espíritos da floresta e corta as relações diretas com os espíritos do Além. Em momento posterior, a educação universal promove a doutrinação das massas com uma visão científica mecanista e reducionista que progressivamente ridiculiza e finalmente elimina a "crença superstiosa" ou a transforma em "folclore" inócuo. Sem as limitações espirituais nas relações com a uma $\mathrm{Na}$ tureza animista, surge a ética ambiental homocêntrica, permitindo o desmatamento desenfreado. A eliminação de normas e práticas sociais e intracomunitárias, como as limitações e obrigações mútuas entre parentes e ancestrais, abre caminho para valores e uso dos recursos de forma individualista, estabelecendo uma ética ambiental egocêntrica, que se associa à adoção de inovações tecnológicas com base na acumulação do capital e na exploração humana (Gottlieb 1996, Shneider, 1990, Thompson, 1995).

O movimento transdisciplinar da Ecologia Política, por sua vez, surge com uma posição 
teórica alternativa, rejeitando o determinismo linear tecnológico e ideológico, em favor da causalidade circular e interrelacionada, abrangendo, ao mesmo tempo, movimentos políticosociais, ideologica, ética ambiental e sistemas econômicos e suas instituições sociais. Dessa forma, transformações ambientais e sociais podem ocorrer através da modificação de qualquer um dos componentes da cadeia de interrelações. A exemplo, uma mudança técnica pode estimular movimentos políticos e sociais, ou, alternativamente, transfomações ideológicas podem promover uma nova ética ambiental que, por sua vez, provoca modificação técnica (Atkinson 1991, Merchant 2005, Pepper 2004, Zimmer \& Basset 2003).

Figura 1 - ÉtICAS AMBIENTAIS ENCANTADAS E DESENCANTADAS

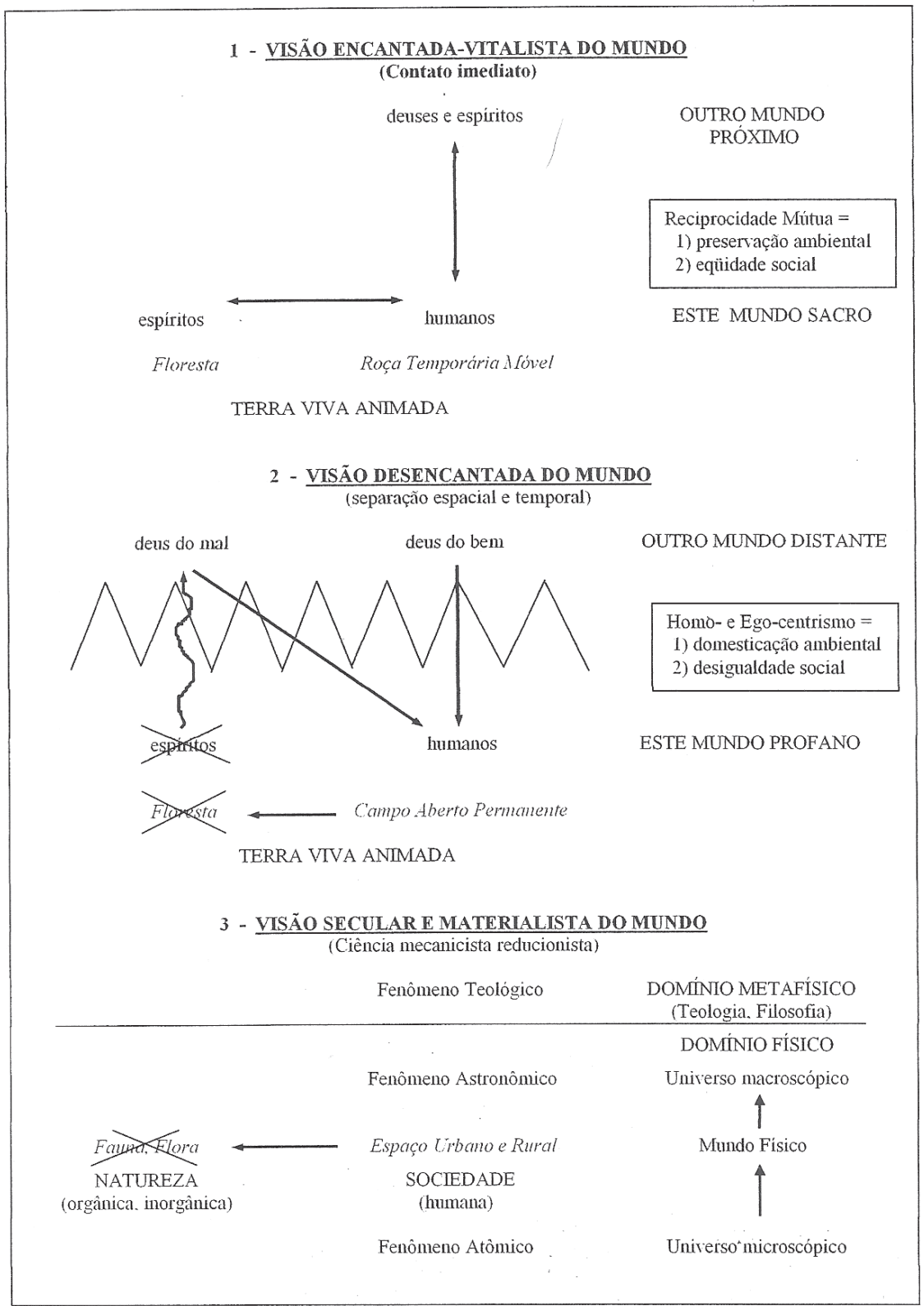

FonTE: PESQUisa DE CAMPO (2005) 
A abordagem da Ecologia Política, intergrando ambiente e cultura, sobressaídos principalmente nas questões ideológicas e da ética ambiental, pode ser fortalecida se integrada ao conceito de paisagem cultural presente na geografia Cultural. Assim sendo, pretende-se unir essas duas abordagens da Geografia, aplicando as novas abordagens sobre o relacionamento cutura-ambiente de autores como Castree (2003), Claval (1999), Cosgrove (2003), Philo e Wilbert (2000), Whatmore (2000), Wolch et.a.lli. (2003). Nessa literatura, a relação sociedade-natureza vai além da mera análise de impactos ambientais e sociais, explorando o significado cultural do ambiente párea definir a identidade humana perante a Natureza e a identidade de diferentes grupos sociais entre si, definindo valores e a ética ambiental na apropriação dos recursos e na convivência com o ambiente.

\section{A pesquisa Qualitativa Sistemática da Ética} AMBIENTAL

O presente estudo representa uma continuação de trinta anos de pesquisa primária sobre o relacionamento entre percepção ambiental e modernização em diferentes regiões do país. Através dos anos os métodos de pesquisa mudaram de uma abordagem etnográfica em direção a uma abordagem qualitativa sistemática que visa a captar melhor a variação socioespacial na relação entre secularização da ética ambiental e a modernização rural (Bicalho \& Hoefle 2002, Hoefle 1983, 1990, Hoefle, 2002).

Desde 1975 pesquisa-se mudança em sistemas agrícolas e estilo de vida na Amazônia, tendo mais de dois anos de trabalho de campo na região. Foram aplicados 527 questionários versando sobre assuntos socioeconômicos junto a famílias de produtores e trabalhadores rurais em quinze municípios do Estado do Amazonas, localizados em frente de expansão agrícola ao longo de rodovias como também em área de ribeirinhos, abrangendo uma diversidade de produtores que pratica desde a agricultura mais tradicional até a mais moderna. A partir de 2005, a percepção ambiental também foi pesquisa na Amazônia, aplicaram-se questionários específicos sobre percepção espacial $(n=48)$, etnoagronomia $(\mathrm{n}=144)$ e ética ambiental $(\mathrm{n}=151)$ em cinco áreas diferentes: 1) Humaitá e Lábrea, 2) Benjamin Constant e São Paulo da Olivença, 3) Itapiranga e Silves, 4) Parintis e 5) Manaus.

Humaitá está localizado na grande frente de expansão agrícola ao longo das rodovias para onde se direcionam imigrantes oriundos de regiões desenvolvidas do país, por via de Rondônia e do Mato Grosso, do Nordeste, por via do Pará e Tocantins, e da própria região. Assim sendo, o trabalho de campo nesse município foi fundamental em função da presença de grande diversidade de atores sociais. Da mesma forma, vários produtores, explorando a horticultura moderna na periferia de Manaus, chegaram de outras regiões do país ou de áreas ribeirinha próximas, criando um complexo quadro social. Por outro lado, a grande maioria dos produtos de Benjamin Constant-São Paulo de Olivença, Itapiranga-Silves e Parintis são ribeirinhos ou ameríndios aculturados, presentes na Amazônia de longa data, que praticam a agricultura tipicamente campesina com orientação semicomercial ou de semisubsistência aos mercados locais e regionais. Também há grande diversidade cultural entre e dentro das cinco áreas de estudo, de acordo com classe social, escolaridade, gêne- 
ro, faixa etária e afiliação religiosa, que permite avaliar a influência de parâmetros culturais junto com prática agrícola e origem regional na ética ambiental.

A análise que segue é dividida em duas partes, cada uma utilizando abordagem epistemológica diferente. A primeira traça uma abordagem tipicamente interpretativa sobre o significado dos diferentes espíritos e criaturas extraordinárias da floresta e dos rios para definir identidade humana e relações étnicas históricas na Amazônia. A principal diferença entre este estudo e outros do mesmo tipo, como por exemplo o de Slater (1994), é o grande número de informantes entrevistados em diferentes áreas da Amazônia, que permite introduzir maior complexidade na análise.

A segunda parte do trabalho via a avaliar as diferentes teses sobre ética ambiental e transformação social. Para fazer isso, a abordagem teórica torna-se mais empirista, senão racionalista, analisando as tendências espaciais estatísticas da variação em crença e descrença em entidades e forças espirituais, segundo diferentes parâmetros socioambientais. Assim sendo, a segunda parte representa uma ruptura com o tratamento etnográfico com ênfase em homogeneidade cultural ou de sub-grupos culturais. Por causa da diversidade de atores sociais envolvidos, a necessidade de utilizar uma abordagem que capta a complexidade cultural é bastante evidente em Humaitá, mas veremos que esse procedimento também tem suas vantangens nas outras áreas do estudo, que à primeira vista aparentam "homogeneidade cultural".

\section{IDENTIDADE HUMANA E ÉTNICA}

Durante a pesquisa de campo quando os produtores "sulistas" foram perguntados sobre os espí- ritos mato específicos da Amazônia, eles freqüentemente responderam que não sabiam de nada e que seria melhor conversar com ribeirinhos, pois estes os conheciam bem. Com isso, podemos perceber como a visão do mundo encantada ou desencantada reflete identidade regional. Além disso, a aparência e o comportamento dos espíritos expressam relações étnicas históricas, muitas vezes identificando o ameríndio, e às vezes o negro, como sendo menos humano, senão animalesco.

Assim sendo, a análise de contos sobre espíritos e criaturas extraordinárias da esfera natural revela idéias sobre a identidade cultural - do humano versus o animal - e a identidade étnica - do colonizador versus o colonizado.

\section{ESPÍRITOS E CRIATURAS EXTRAORDINÁRIAS DA FLORESTA}

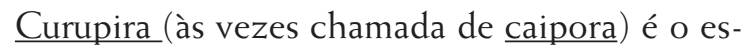
pírito da floresta mais conhecido. É considerado o "chefe da floresta" ou a "mãe da floresta" e como tal feminina. Ela mora na floresta virgem, em áreas interfluviais e nas cabeceiras dos rios, onde mora pouca gente, de forma que só caçadores têm contato com este espírito. Curupira come fruta nativa e caça animais como gente. Como protetora dos animais, porém, ela pode atrapalhar a caça, fazendo com que o caçador se perca na floresta ou desarmando suas armadilhas. Geralmente, a curupira se limita a bater no caçador e nos seus cachorros com golpes invisíveis ou jogar pedras neles. Em alguns contos, porém um caçador é achado morto, amarrado numa árvore e isso é atribuído à curupira.

Curupira é um espírito encantado porque tem a capacidade de se tornar invisível, mas quando visto tem a forma de uma pequena cabocla ou ame- 
ríndia, embora em alguns relatos seja um homem negro. Sua aparência e comportamento misturam traços animais com humanos e os traços humanos são ameríndios. Ela não veste roupa, tem cabelo cumprido que cobre a cara e tem pêlo no resto do corpo. Seus pés são para trás e na Amazônia Ocidental ela tem um pequeno rabo. Curupira não tem capacidade de fala e só faz sons guturais. Assim sendo, ela apenas tem uma "semelhança humana" e como tal ocupa uma posição intermediária entre gente e animais. Um homem cabeludo, que fica muito tempo no mato e que vomita sua comida recebe o apelido "curupira", insinuando que tem aparência e comportamento não-humanos: clássica metáfora animal-humana (cf. Urton 1985).

Curupira adora fumo de rolo e particularmente cachaça que um caçador pode deixar no mato para que, em troco, ela não atrapalhe a caça. Isso pode ser interpretado como um ato de reciprocidade, limitando a caça predatória, como nas teses da Ecologia Espiritual. Apesar disso, nenhum entrevistado expressou conscientemente essa idéia, diferentemente do que é encontrado na literatura para ameríndios (Reichel-Dolmatoff 1976) ou em pesquisa anterior encontrado em área de Mata Atlântica (Bicalho e Hoefle 2002). Por outro lado, a idéia está presente num relato do Inferno como um lugar onde os condenados são obrigados a comer a carne podre de todos os animais que mataram acima de suas necessidades alimentares.

O mapinguari é outra criatura noturna da floresta virgem, que é menos conhecida do que a curupira. Tem uma aparência similar a esta, ao ponto que alguns informantes o identificam como o parceiro da curupira. Contudo, o mapinguari é muito maior e perigoso, pois, mata e come caça- dores que se aventuram na floresta à noite. Além disso, o mapinguari tem sua boca na barriga, uma carcaça à prova de bala e só pode ser morto quando se atira em sua boca no momento em que ele grita. Essa criatura é considerada muito feia e fétida de forma que uma pessoa com mau cheiro ou hábito de sair a noite recebe apelido de "mapinguari".

O juma também conhecido como o índio jurupari, é um indígena muito alto com cabelo cumprido, olhos feios e apenas um grande pé deformado. Eles podem formar casais que vivem na mata distante. Jumas vestem roupa ameríndia, um pano para o homem e tanga de miçanga para a mulher, ou eles simplesmente andam nus. Algumas pessoas acham que juma pode falar enquanto outros acham que não, mas todos afirmam que ele assusta caçadores na floresta com um grito que parece um disparo de espingarda. Alguns informantes consideram juma inofensivo porque só assusta pessoas ou cospe sementes nelas. Outros, ao contrário, afirmam que juma ataca e come gente como mapinguari.

Martin é um espírito invisível que se manifesta como um vento repentino na floresta profunda. Como é invisível, somente um apito alto sinaliza que está por perto. Esse ente vaga na floresta sem lugar fixo e é relativamente inócuo, pois, no máximo, só causa susto quando dá um lambido em algum caçador.

Relatos de saci pererê são raros na Amazônia ribeirinha e são mais comuns à zona de expansão da fronteira agrícola onde se encontram imigrantes do Sul e do Sudeste mesmo se estes raramente acreditam na sua existência. As histórias em $\mathrm{Hu}$ maitá são típicas daquelas regiões: saci é caracterizado como um pequeno menino negro com uma perna que veste shorts vermelhos e um chapéu 
preto, fuma um cachimbo e monta cavalo. Contudo, Há alguns relatos que "misturam" entes. Um agricultor em Humaitá o chamou de "martin pererê" e deu uma descrição de curupira. Outro produtor na periferia de Manaus disse que saci existia aí no passado quando ainda havia mata no local. Sua caracterização combinou a aparência de saci com o comportamento de curupira de fazer pessoas se perderem na floresta e de se alimentar de caça. Assim sendo, no nível de diferentes relatos individuais, são encontradas transformações e inversões clássicas de traços e comportamento que, na abordagem de "consciência coletiva", seria considerada a confusão de diferentes mitos "típicos".

\section{ESPÍRITO E CRIATURAS EXTRAORDINÁRIAS DOS RIOS QUE SE TRANSFORMAM EM HUMANOS}

A crença em cobra grande é muito comum no alto Amazonas e baixo Madeira, uma figura de destaque nas apresentações do Boi Bumbá. Nos relatos, a cobra grande é de cor preta e seu tamanho varia de 30 metros até mais de 200 metros. Tem olhos vermelhos em brasa e ataca pescadores, engolindo a canoa com todos dentro. Alguns informantes afirmam que a cobra grande tem a capacidade de transformar-se em mulher, subir na terra e carregar criança de volta para o rio.

Certos botos vermelhos (como a cor rosa é percebida na Amazônia) também têm a capacidade de tranformar-se em pessoas e subir na terra. Um lindo jovem branco, vestido todo de branco, aparece de repente numa festa à noite ou de frente para mulher lavando roupa ou tomando banho no rio no fim do dia e a encantada. Alternativamente, o boto pode aparecer com cabeça de boto e corpo de homem vestido apenas de sapato, de raia na cabeça como chapéu e de peixe elétrico como cinto. Diferentemente de puxinã, o golfinho cinza ("preto" localmente) que pode ajudar pessoas se afogando, o boto rasga rede e é visto como malvado pois "faz mal" engravidando moças. Ele enfeitiça as mulheres de forma que elas se rendem, pulam no rio e o acompanham até seu lar no fundo do rio, de onde elas nunca voltam. Também, botos podem assustar um pescador aparecendo subitamente com um osso ou caveira humanos trazidos do fundo do rio.

Bem como os deuses da mitologia grega, o boto serve para explicar uma gravidez indesejada. Este tipo de gravidez pode resultar na mistura de espécies e na barriga da mulher a criança se movimenta como um peixe e faz barulhos de boto. Em um caso, a mulher foi dar à luz no hospital municipal onde o "pai" foi buscar seu filho, talvez acobertando o fato de que a criança foi dada em adoção. A maioria das pessoas é descrente da existência do boto, pois soa como uma desculpa muito conveniente para explicar uma gravidez fora do casamento. Alguns informantes brincaram dizendo que o boto foi inventado para não pagar pensão à criança. De fato, a crença serve para evitar conflito em pequenas comunidades ribeirinhas onde todos são parentes e amigos, pois projeta o problema para fora, para a figura do boto, que alguns protestantes identificam com o demônio, sendo o único espírito do mato que não é Deste Mundo.

A crença na iara e na sereia é rara nesta parte da Amazônia, mas, quando existe, é inversa à do boto. A sereia é uma mulher branca ou indígena muito bonita com metade do corpo pra cima em forma humana e outra metade em forma de peixe, às vezes com é de pato. A sereia pode ser encon- 
trada nos rios, mas geralmente ela vive no mar. Ela seduz pescadores e os carrega para sua moradia no fundo do mar de onde não voltam mais. Como o boto, a sereia também pode transformar-se numa mulher inteira e subir na terra atrás de um homem para carregar consigo. Assim sendo, a sereia e o boto foram um par de invenções simbólicas com forte conotação sexual. O boto é um homem branco ou meio peixe que seduz as caboclas, e a serei é uma mulher branca ou indígena que seduz os caboclos.

\section{PESCADORES QUE SE TRANSFORMAM EM ANIMAIS E ESPÍRITOS}

Uma visage ou visagem é um espírito ou vulto na forma de fantasma de uma pessoa morta que não se "salvou" (não foi ao Céu). Vestida de camisola branca e sem cabelo, aparece e desaparece repentinamente ao longo de uma trilha escura ou em volta da casa, à noite, e a pessoa que a vê fica imóvel, petrificada de medo. A visagem não costuma atacar gente, mas o susto é terrível. O vulto é a alma perdida de alguém que era mal e agora vaga na solidão de um inferno terrestre, uma idéia comum ao catolicismo popular do Nordeste (Hoefle, 1997).

A transformação de homem em lobisomem é outro tipo de castigo divino, nete caso para quem nunca foi batizado. Logo antes da meia noite, na Quarta-Feira de Páscoa, o pescador é transformado numa espécie de porco ou cachorro horroroso, que é obrigado a correr sete freguesias, o que na Amazônia não é fácil, considerando o tamanho das freguesias. $\mathrm{Na}$ sua corrida, o lobisomem pode parar para roer ossos velhos de animal ou peixe e para comer crianças encontradas no caminho. Com a aproximação de um lobisomem, os cachorros ficam nervosos e começam a latir, mas não ousam atacar a criatura. Se o lobisomem é surrado, ele volta à forma humana e qualquer ferimento sofrido durante a corrida aparece no corpo no dia seguinte, confirmando as suspeitas que as pessoas podem ter sobre o comportamento estranho de um vizinho.

\section{IDENTIDADE HUMANA E RELAÇÕES ÉTNICAS COLONIAIS}

No nível mais geral, a diferença entre as criaturas extraordinárias e ambíguas, em um lado, e a gente, no outro, serve para definir o que é humano em termos de aparência física e comportamento social. Curupira tem alguns traços humanos, por exemplo, andar em dois pés ou adorar fumo e cachaça, mas ela ainda é peluda, não veste roupa, tem força super-humana e o poder de invisibilidade. Mapinguari parece um pouco com a curupira, mas é muito grande, possui uma boca no lugar errado e fede terrivelmente. Gente veste roupa, toma banho todo dia e só caçadores saem à noite.

Todas as criaturas descritas nas seções acima perpetuam atos violentos ou pregam brincadeiras assustadoras em pessoas. Mapinguari e cobra grande são predadores que podem atacar e comer gente como uma onça. Curupira reina sobre os animais silvestres que o homem caça, ela é um rival e sua violência contra um caçador pode resultar na morte do mesmo, porém ela não chega a comer gente. Lobisomens, por sua vez, são homens que temporariamente assumem aparência e comportamento animal, e que foram castigados por não observarem exigências religiosas. Também a visagem sofre infelicidade e desgraça por causa de pecados perpetuados quando uma pessoa era viva.

Botos e sereias são criaturas que se transformam temporariamente em gente para tentar pessoas 
sexualmente, fazendo com que eles abandonem suas famílias para viver numa moradia no fundo do rio ou do mar. Alguns relatos sobre curupira possuem um teor sexual. Neles, ela tenta capturar um caçador para ser seu parceiro, porém, como ela é feia demais para segurar um homem, este deve ser amarrado em uma árvore para não fugir.

A crença em almas perdidas fecha o círculo na relação entre gente e criaturas extraordinárias quando alguns informantes afirmam que os botos encantados são as almas perdidas de pessoas que se afogaram. Uma alma perdida geralmente aparece para pedir que alguém termine uma tarefa inacabada na Terra, como, por exemplo, cumprir uma promessa. Além disso, a alma perdida aparece porque quer levar um vivo junto para ter companhia no seu inferno solitário. No caso de uma alma perdida em forma de boto, esse inferno seria sua moradia no fundo do rio.

Num outro nível, criaturas encantadas representam as relações históricas entre grupos étnicos na Amazônia. O boto encantado é um jovem branco e como tal é considerado bonito. Juma é um ameríndio deformado e a curupira uma cabocla peluda. Ambos moram na floresta como selvagens. Saci é um negro que vive no mato. Tais criaturas são imagens inversas do colonizador europeu historicamente dominante no país. Em história oficial e popular, o colonizador é o civilizado que desbravou os sertões do país e arregimentou os outros grupos étnicos para este processo, enquanto as criaturas encantadas representam ameríndios e africanos vivendo no mato por fora da sociedade colonial de dominação européia. Informantes comumente fizeram afirmações como, "Mapinguari é um índio transformado" ou "Curupira é uma velha índia que se mudou para sua forma atual", ou ainda, "Curupira dominou os índios bravos e transformou eles em caboclos".

Finalmente, no nível de grupos sociais definidos por região de origem, crença e descrença em criaturas encantadas separam a população local dos imigrantes que chegam de outras regiões do país. Quando perguntados sobre espíritos do mato específicos da Amazônia, os imigrantes respondiam professando sua descrença ou simplesmente dizendo que não os conheciam e que tais crenças eram típicas dos ribeirinhos e não deles. Os imigrantes podiam, por ventura, amenizar sua atitude perante aos ribeirinhos dizendo que quando eram crianças no Sul ou no Nordeste escutavam histórias sobre encantados lá, mas que nunca os tinham visto. $\mathrm{O}$ produtor de fora podia ainda responder que simplesmente não acreditava em encantados de qualquer tipo, em qualquer lugar.

\section{Identidade Regional, ModernizaÇão RuRal E}

\section{Diversidade Cultural}

A ética ambiental é associada à identidade social e existe uma sutil variação desde crença até a descrença nos elementos de uma visão de mundo encantada, que agora será explorada através da experiência socioespacial de diferentes indivíduos. A análise da ética ambiental aqui analisada é divida em três dimensões: 1) a crença nos espíritos do mato que fazem parte Deste Mundo e que geralmente só afetam caça e a pesca, 2) a crença na interferência de forças sobrenaturais do Outro Mundo, no caso de Deus e do diabo, e Deste no caso do olho gordo (mal olhado), que afetam a saúde da lavoura, dos animais e da gente e 3) a crença num mundo visto como vivo, que pode impor limites éticos à exploração agrícola. 
A atuação dos espíritos do mato perante as atividades humanas é tratada acima, de forma que aqui só é preciso descrever a atuação das forças sobrenaturais e o vitalismo. $\mathrm{Na}$ ajuda divina, Deus vem auxiliar o agricultor que sofre problemas naturais (praga, etc.). No dano diabólico, o Satanás causa a morte da lavoura e dos animais ou leva pessoas a agir por ele. O olho gordo, o olhar de uma pessoa geralmente invejosa, causa morte de lavoura, animais e pessoas. Finalmente, no vitalismo, a terra e água são consideradas vivas porque alimentam as plantas e os animais e se movimentam de um lugar para outro, tornando necessários cuidados com sua força vital para manter a fertilidade e capacidade de sustentar a vida.

À primeira vista, comparando a população de origem local, ao lodo dos rios e das rodovias e de outros estrados do Norte e do Nordeste, num lado, com população oriunda de regiões mais desenvolvidas, como o Centro-Oeste, Sudeste e Sul, num outro, o uso de sistema agrícola tradicional ou moderno parece fundamentar a ética ambiental. Informantes de produtores de regiões onde se pratica a agricultura tradicional acreditam bem mais nos espíritos da floresta e dos rios, na atuação de agentes sobrenaturais e espirituais na agricultura e no vitalismo da terra e da água do que indivíduos que chegam do Centro-Sul, apontando para tese do determinismo tecno-econômico da ética ambiental (Figura 2, 3, 4).

Contudo o alto nível de descrença da população oriunda da zona urbana da Amazônia mostra que a situação é bem mais complicada e que talvez outros fatores como nível de escolaridade e posição de classes seja mais importante do que o suposto controle técnico de risco natural para agricultura moderna. Indivíduos de origem urbana são particularmente descrentes dos espíritos dos rios, mas muitas pessoas têm suas dúvidas sobre o boto, o que faz cair o nível global de crença neste tipo de espírito quando comparado com a crença nos espíritos da floresta.

\section{FigURA 2 - CRENÇA NOS ESPÍRITOS DA FLORESTA POR ORIGEM REGIONAL}

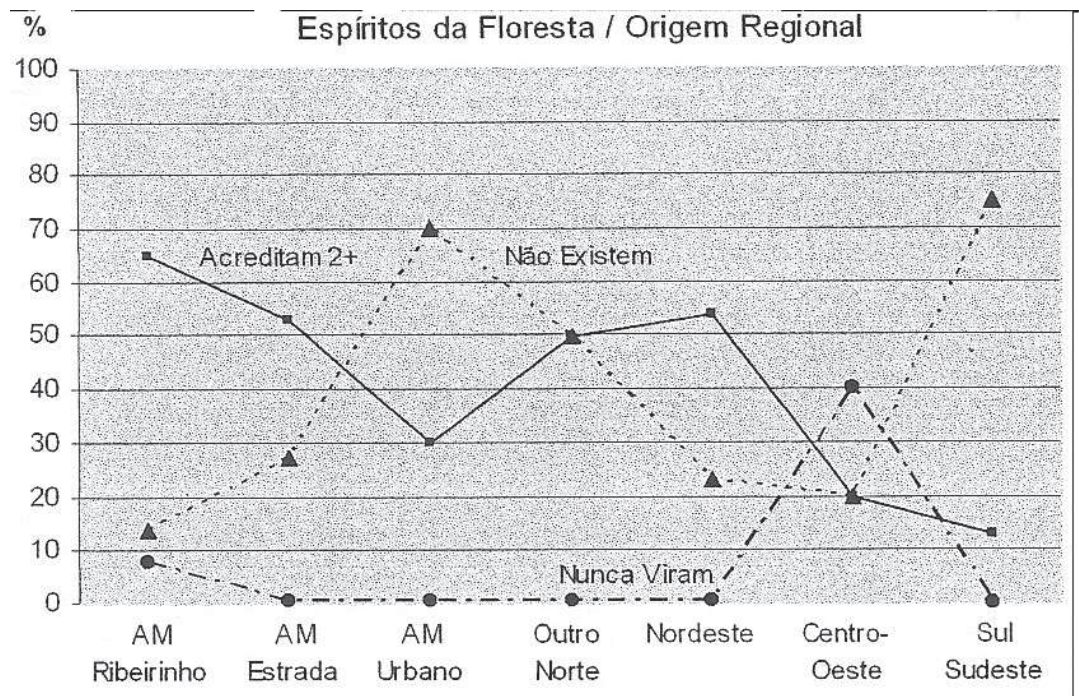

FONTE: PESQUISA DE CAMPO (2005) 
A variação de crença e descrença na interferência divina e diabólica e a interferência do olho gordo na agricultura é muito forte, embora menos para a visão vitalista da Natureza, também sugerindo a importância do nível de escolaridade do entrevistado. Somente para o olho gordo foram encontrados alguns comentários ligando a descrença ao uso da técnica agrícola moderna.

Quando a crença é relacionada aos sistemas agrícolas específicos, fica evidente a importân- cia de classe social e nível de escolaridade (Figuras 5,6$)$. Produtores ribeirinhos de fato acreditam mais nos espíritos em função de seu baixo nível de escolaridade, e não por causa de menor controle de processos naturais. A relação de crença sobe e desce de acordo com a posição social se o entrevistado for produtor ou trabalhador e, portanto, de acordo com condição financeira que possibilita acesso a níveis mais elevados de educação.

FIGURA 3 - CRENÇA NOS ESPÍRITOS DO RIO POR ORIGEM REGIONAL

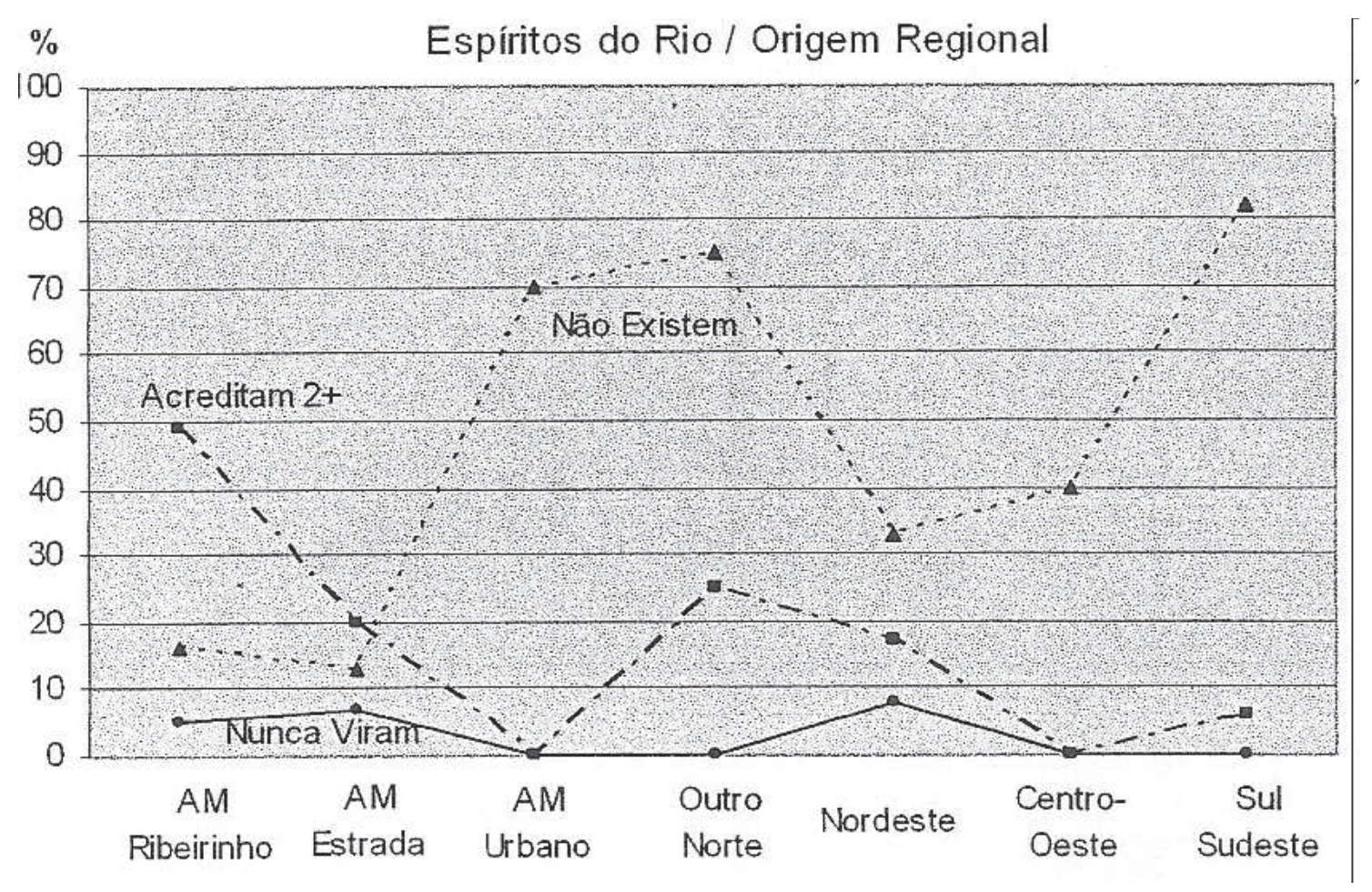

FONTE: PESQUISA DE CAMPO (2005) 


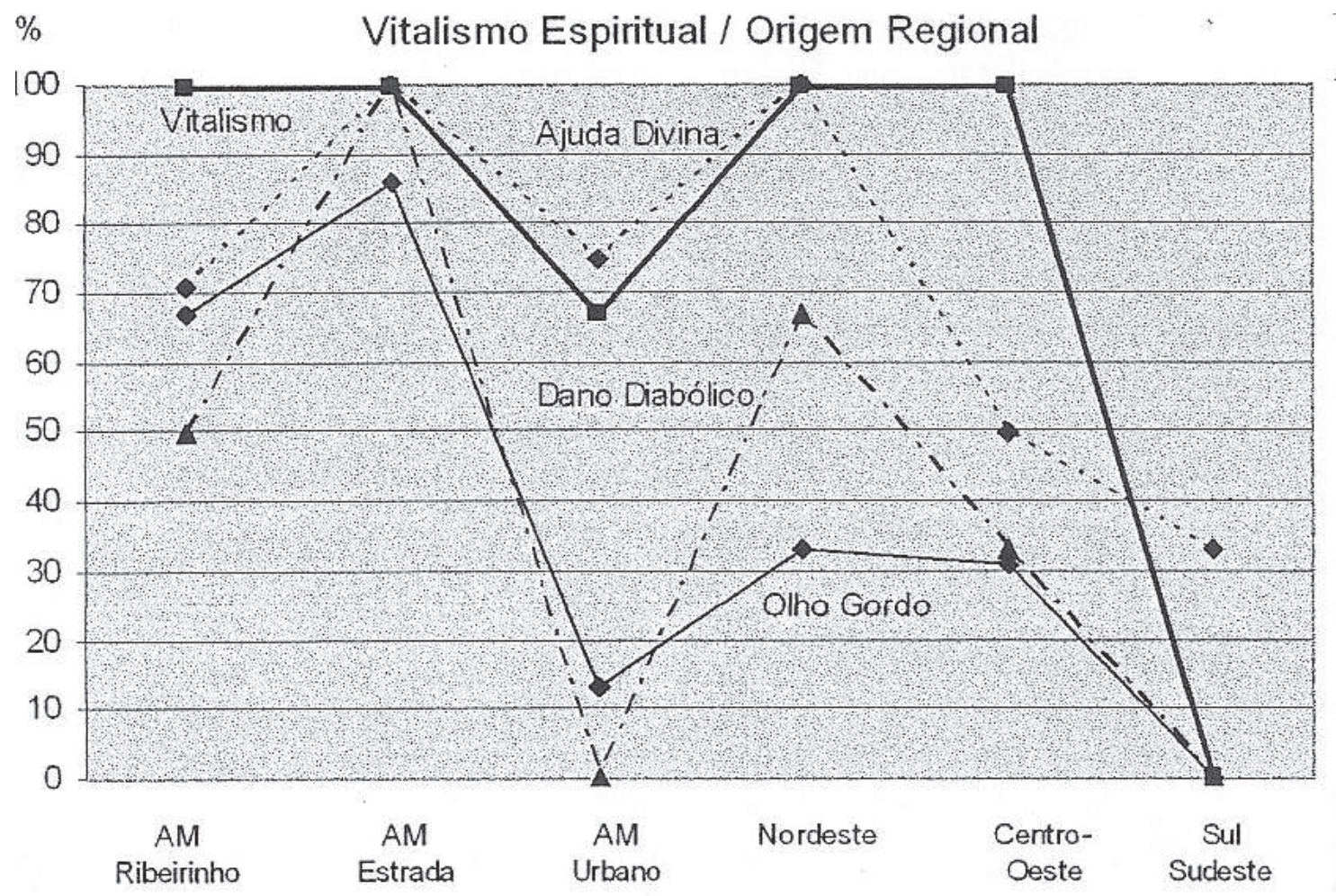

Fonte: Pesquisa de campo (2005)

$\mathrm{Na}$ verdade, as atividades agrícolas de produtores ribeirinhos de terra firme envolvem menor risco natural e do mercado, como também é o caso de produtores tradicionais de alimentos e de pecuaristas ao longo das estradas. Agricultores de alimentícios plantam cultivos tradicionais à Amazônia bem adaptados aos riscos ambientais da re- gião. A mandioca, em particular, é raramente atacada por praga e, em conseqüência, são utilizados poucos insumos modernos que aumentam os custos de produção e os riscos de mercado. Não se ganha muito dinheiro plantando mandioca, mas pelo menos a safra e a colocação no mercado são certas. 


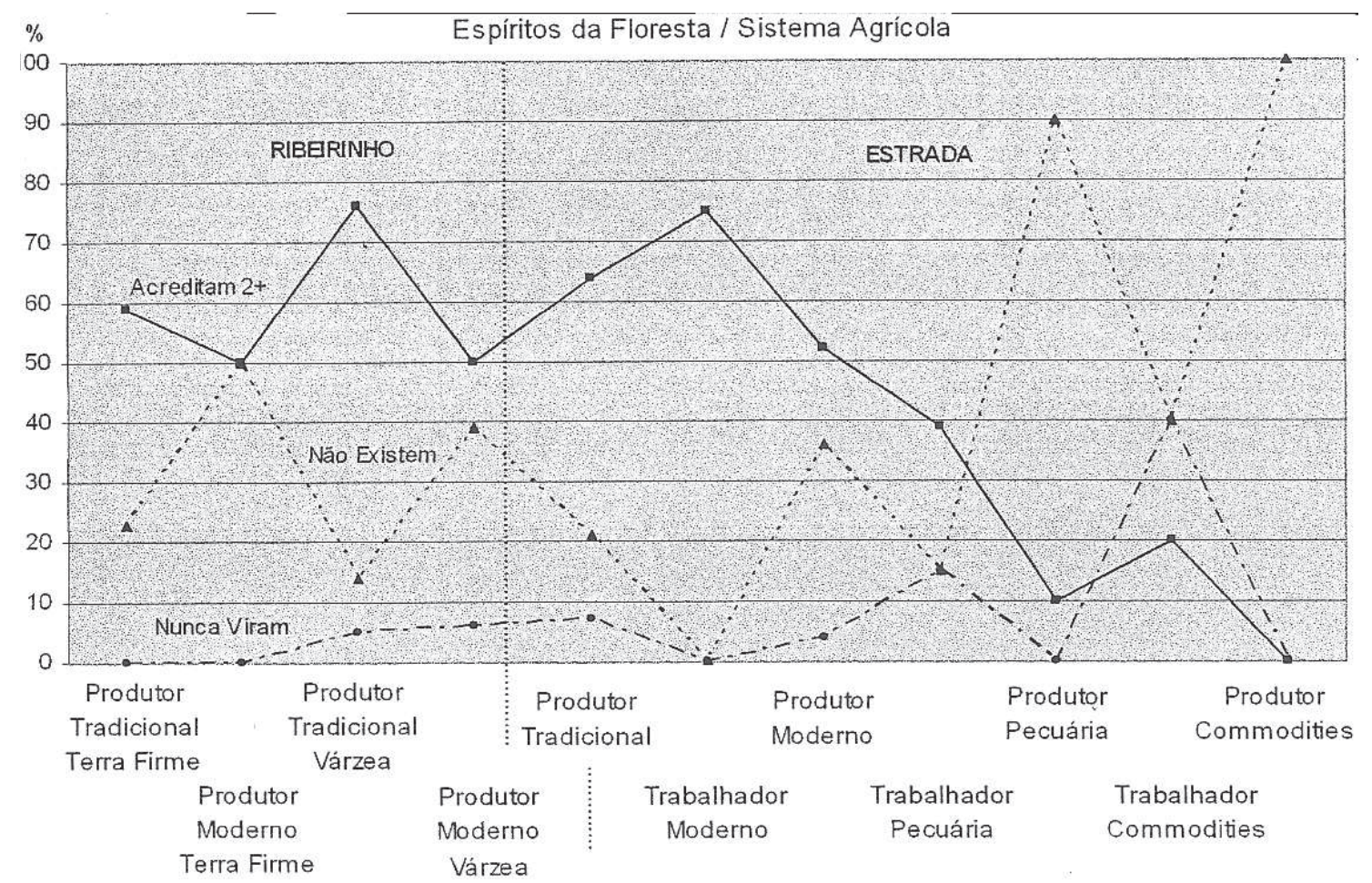

FONTE: PESQUISA DE CAMPO (2005)

Já os cultivos altamente comerciais envolvem grande risco ambiental e de mercado. A produção de hortaliças e de grãos para exportação é muito exigente no uso de insumos modernos de alto cutos, que nem sempre resolvem problemas com as pragas que aparecem com maior freqüência nessas lavouras, que ainda são sujeitas à grande risco de mercado que tem um fundo ambiental. A soja em particular envolve grande risco de mercado que tem um fundo ambiental. A margem de lucro é muito apertada de forma que, se qualquer variação climática a produtividade não atingir patamar elevado, o produtor tem prejuízo um problema que pode ser ainda mais agravado pela valorização do real frente ao dólar americano.
O uso de tecnologia moderna tem sua influência sobre ética ambiental, mas a influência é indireta. Na grande produção de grãos, o uso de tecnologia moderna provoca extensivo desflorestamento e disparidade social, que, por sua vez, levam à perda da tradição oral sobre os espíritos do mato. O caso excepcional de um jovem, da periferia de Parintins, que acredita nos espíritos apesar de sua alta escolaridade nos dá pistas. Ele afirmou que os espíritos existiam no local no passado quando a área ainda era mais florestada. Naquela época seu pai teve contato com eles e lhe contou histórias a seu respeito. Hoje não exsitem mais localmente, mas ele acredita que ainda existem em zonas florestadas afastadas da cidade. Podemos ver como a domesticação da paisagem eliminou a 
moradia dos espíritos, de forma que o rapaz não teve contato direito e possivelmente não contará as histórias para seus filhos, fazendo com que na terceira geração, após o desmatamento, as histórias de espíritos da floresta sejam perdidas na tradi- ção oral. Os informantes que somente escutaram histórias de seus avôs frequentemente tinham pouco conhecimento detalhado sobre os espíritos e, às vezes, apenas conheciam o nome, sem saber mais nada sobre eles.

\section{FiguRA 6 - CRENÇA EM AGENTES SOBRENATURAIS E VITALISMO POR SISTEMA AGRÍCOLA}

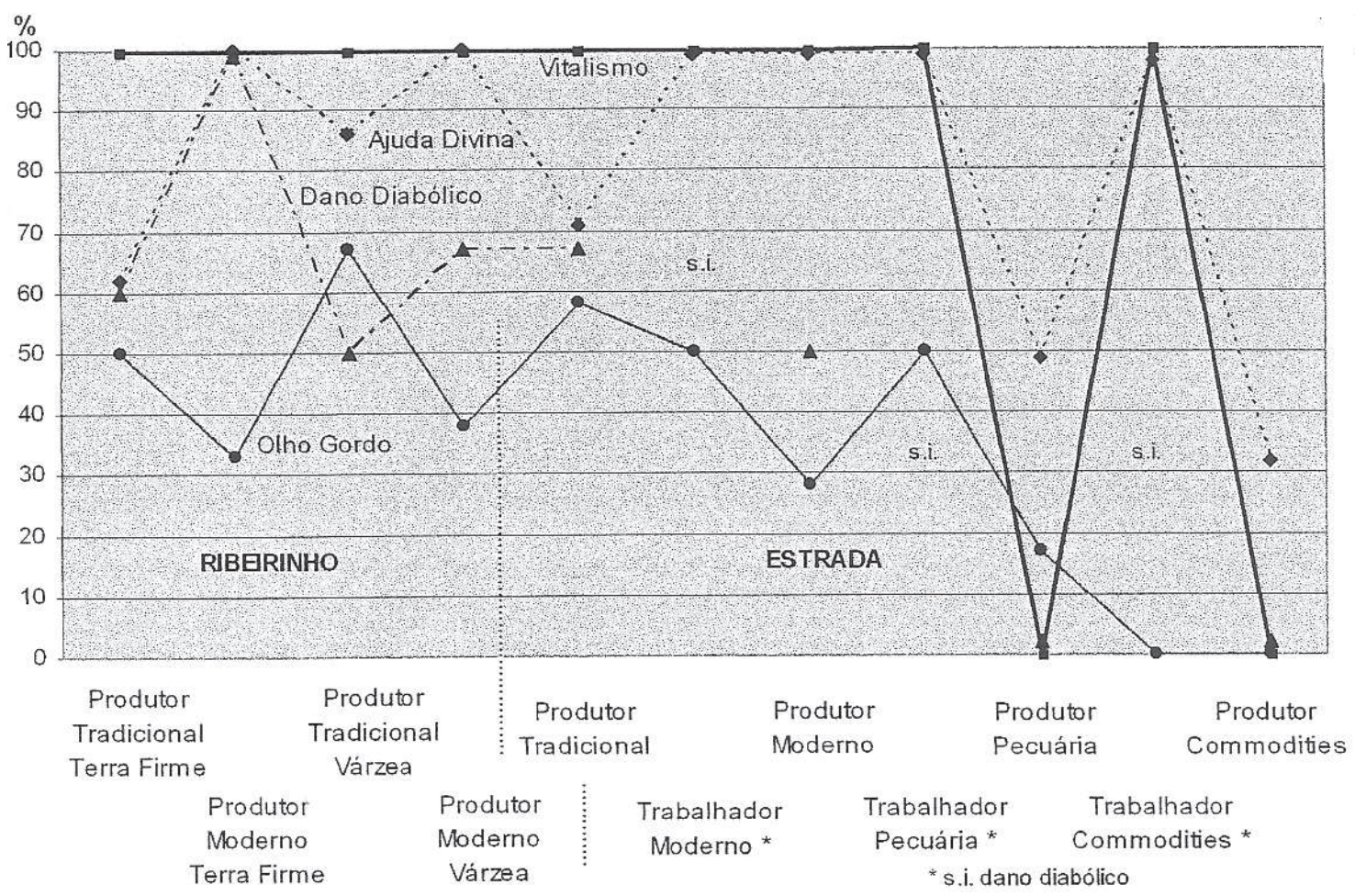

Fonte: Pesquisa de CAMPO (2005)

Contudo, no caso da horticultura praticada na periferia das cidades maiores, talvez a principal causa do desflorestamento não seja a agricultura moderna e sim a expansão urbana. A família do próprio rapaz da periferia de Parintins citado acima estava, no momento da entrevista, loteando partes de sua propriedade para vender para moradores da cidade. Além disso, a horticultura praticada em locais mais distantes da cidade não promove desflorestamento porque é uma atividade agrícola intensiva praticada em pequenas áreas. A pecuária extensiva, por sua vez, não é moderna e provoca extensivo desflorestamento na Amazônia.

A relação mais linear existe entre nível de escolaridade e descrença nos espíritos e no vitalismo (Figura 7,8 ). Desde o nível primário, alunos aprendem que os espíritos são "folclore", apenas contos populares sobre entes que não existem, mesmo que tenham valor recreativo. A partir do segundo segmento do primeiro grau (o antigo 
ginásio), são ministradas matérias de Biologia e outras ciências naturais que instilam uma visão de mundo materialista e mecanicista. Nessa visão do universo, o fenômeno é dividido em matéria orgânica e inorgânica e só é admitida à existência empírica de processos materialistas, não- espirituais, sendo o resto domínio de filósofos e teólogos, senão superstição. Quanto maior o nível de educação dos informantes, quanto mais eles respondiam com veemência que não acreditavam em tais tolices e ainda ficavam irritados com o pesquisador por ter duvidado de sua racionalidade. Com isso, vemos que um elemento da esfera ideológica - educação formal - provoca a secularização de outro elemento ideológico - a ética ambiental.

FIGURA 7 - CRENÇA NOS ESPÍRITOS DA FLORESTA POR NÍVEL DE ESCOLARIDADE

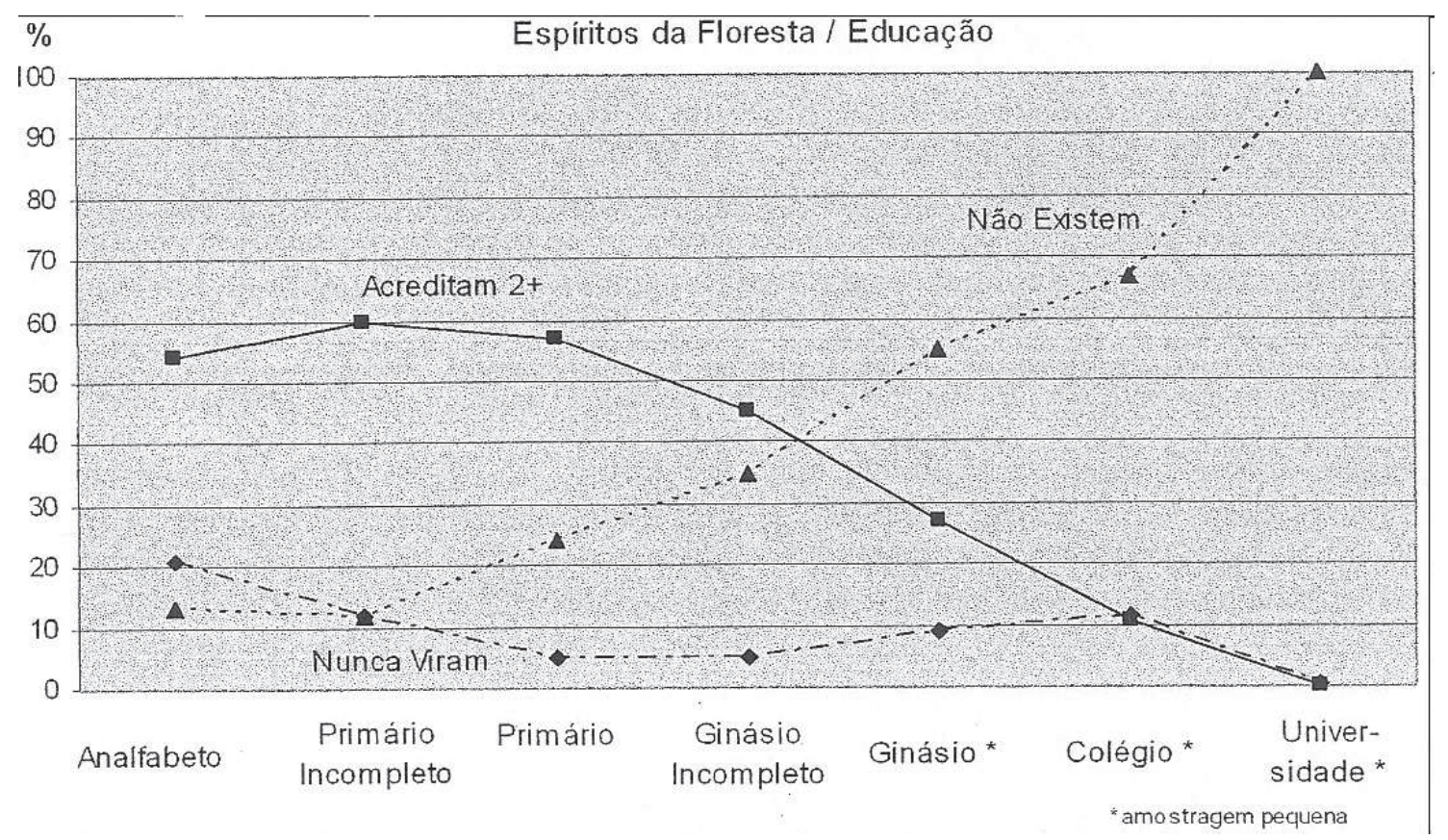

Fonte: Pesquisa de CAMPO (2005) 


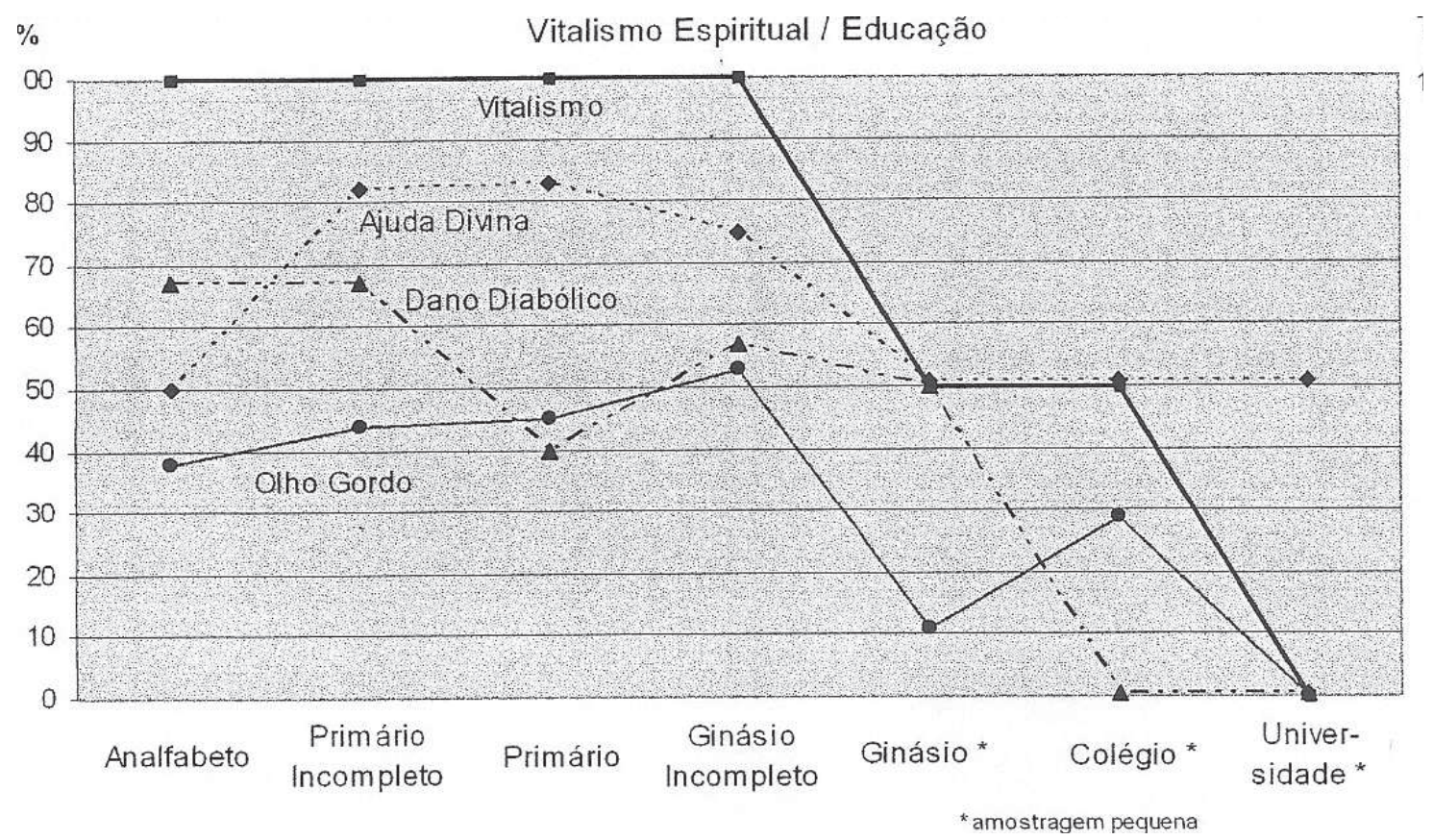

FONTE: PESQUISA DE CAMPO (2005)

Contudo, o processo de secularização entre os entrevistados de maior escolaridade não é total, como mostra o caso excepcional de um técnico do serviço de extensão agrícola que, por sua formação universitária, é ciente do fato de que não devida acreditar na agência de Deus no mundo material, mas que por sua forte religiosidade, continua acreditando. Ele ainda observou que existe grande fé na região de forma que a secularização que ocorre é seletiva e a religião convive com a ciência pregada na educação formal.

Agora, mesmo tendo destacada a importância da educação formal no processo de secularização, é interessante notar que sua influência também não é perfeitamente linear. As mulheres e os jovens são as pessoas que mais estudam de forma que era de se esperar que eles tivessem maior descrença em relação aos espíritos, o que, de fato, não acontece. Por todas as faixas etárias, a crença nos espíritos do mato é equilibrada, em torno de 50\% dos espíritos da floresta e $25 \%$ para os dos rios. Os jovens om menos de 30 anos acreditam menos na agência de forças sobrenaturais do que os velhos com mais de 70 anos, mas eles acreditam mais do que os indivíduos de meia idade, refletindo a maior escolaridade de alguns informantes nessa faixa etária. As mulheres, por sua vez, acreditam mais nos espíritoos do mato do que os homens, um pouco menos na agência de forças sobrenaturais, mas um pouco mais na visão vitalista da Natureza.

Finalmente, a questão de afiliação religiosa e crença nos espíritos reforça a importância do nível de escolaridade (Figuras 9,10). Nas últimas décadas, o catolicismo popular há séculos na Ama- 
zônia, sofre perda de fiéis para os grupos protestantes, cuja visão do mundo pode ser desencantada, na qual os espíritos do mato são considerados manifestações do Diabo. Contudo, os pentecostais e os cruzistas (uma seita católica dissidente das reformas vaticanas dos anos de 1960 que na prática é próxima ao fundamentalismo protestante) acreditam mais nos espíritos do mato de que os católicos. É verdade que os pentecostais acreditam um pouco menos na agência sobrenatural na prática agrícola, mas, por outro lado, eles têm uma fixação na interferência diabólica na vida das pessoas. Os poucos luteranos encontrados na área de estudo pouco acreditam nos espíritos do mato ou na interferência de agentes sobrenaturais na agrícola, mas isso decorre de seu elevado nível de escolaridade e de sua origem regional do Sul, e não porque sua religião demonizou os espíritos. Dos outros grupos religiosos, o cruzista tem o menor nível de escolaridade, seguido pelo pentecostal.

FIGURA 9 - CRENÇA NOS ESPÍRITOS DA FLORESTA POR AFILIAÇÃO RELIGIOSA

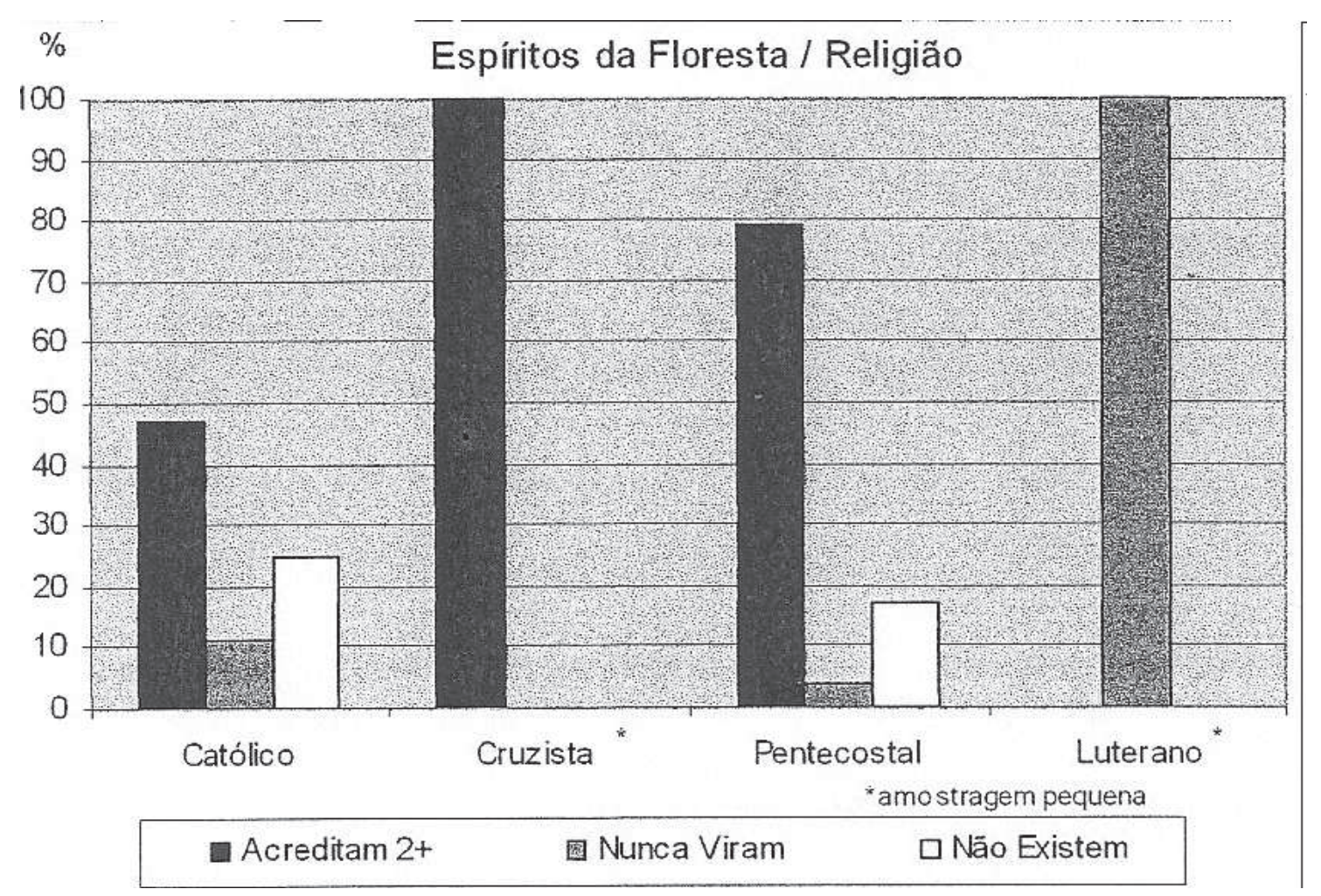

Fonte: Pesquisa DE CAMPo (2005) 


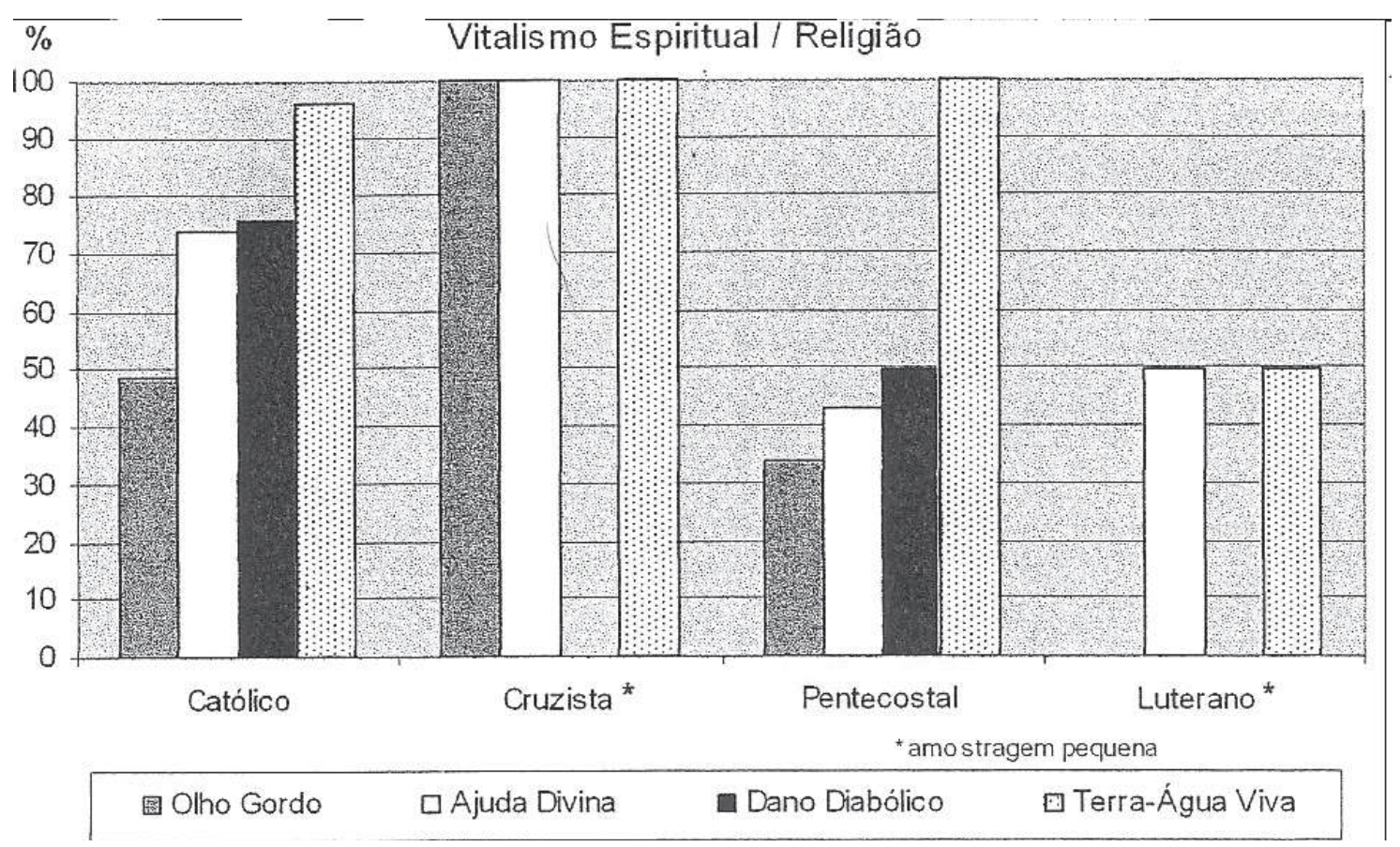

Fonte: Pesquisa De CAMPo (2005)

\section{CONCLUSÃO}

A relação entre modernização rural e ética ambiental na Amazônia Central e Ocidental é bastante complexa, não podendo ser reduzida ao determinismo tecno-econômico, nem ao determinismo ideológico (Figura 11). Observa-se que enquanto foi constatada a relação direta entre modernização agrícola, desflorestamento e desigualdade social, a ética ambiental não é resultante direta da modernização tecnológica. O uso da agricultura moderna não provoca o desencantamento porque possui maior controle de processos naturais, pelo contrário, vimos que há maior risco ambiental e de mercado na agricultura comercial. A relação é indireta, atuando através da domesticação da paisagem pelo desmatamento e o maior uso do espaço, mesmo que sem mudança e intensificação técnica, como é o caso da pecuária extensiva. Outro fator de forte influência na ética ambiental é a disseminação de visão de mundo secularizada e mecanicista pela educação formal. Assim, não é simplesmente pelo controle de processo naturais e pela diminuição de riscos ambientais pela técnica moderna que ocorre a secularização ideológica sobre o ambiente.

Veremos que a questão é muito mais complexa, multi-fatorial, sobressaindo processos da relação de uso do espaço e de formação de conhecimento e exposição e absorção de novas ideologias. Essas ideologias são disseminadas mais sistematicamente no segundo e no terceiro graus, aos quais somente as classes média e alta têm acesso 
em ambiente urbano. A agricultura comercial e o alto níveis de educação formal se reforçam de for- ma que aspectos econômicos e ideológicos interagem, não havendo determinismo uni-direcional.

\section{Figura 11 - UM MODELO COMPLEXO DE DESENCANTAMENTO}

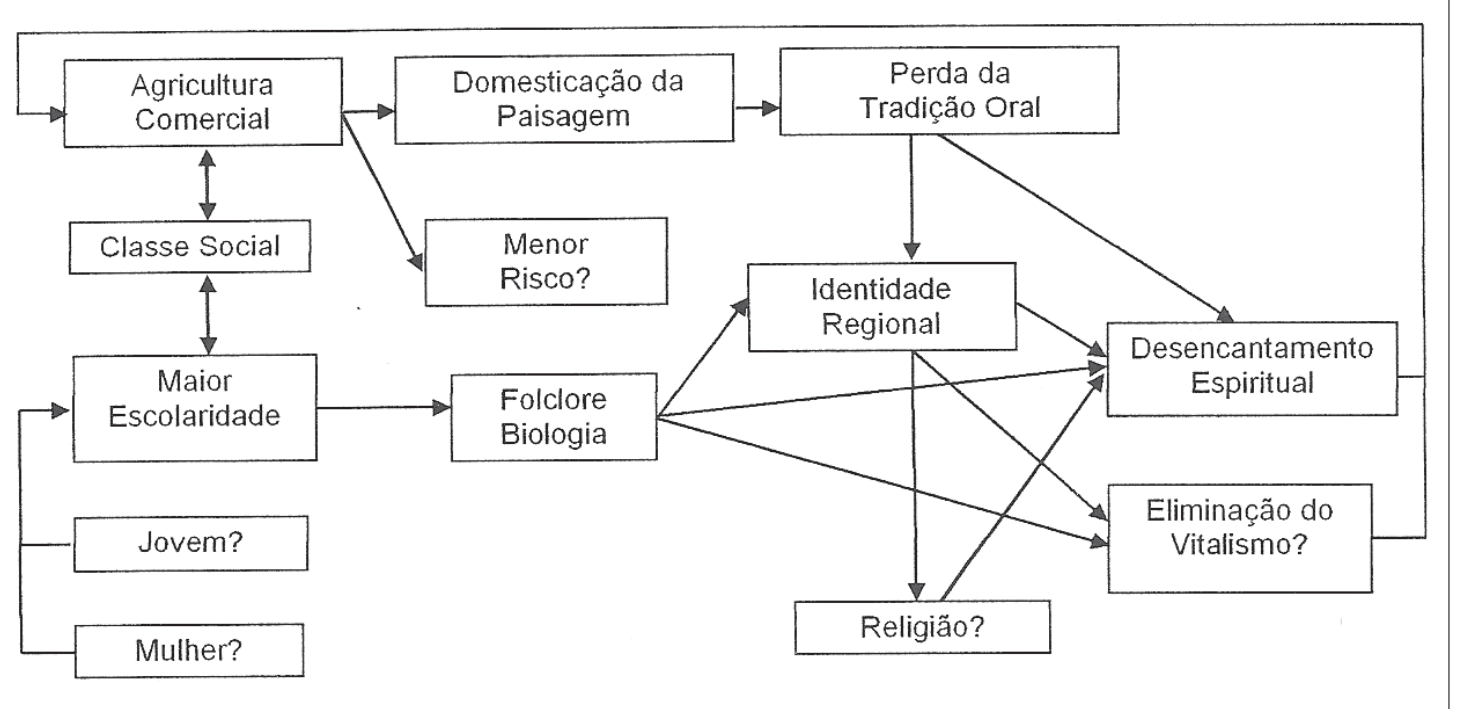

\section{AgRADECIMENTO}

A pesquisa foi financiada pelo Conselho Nacional de Desenvolvimento Científico e Tecnológico (CNPq - Brasil), o Institut Français de Biodiversité (IFB - França) e o Institut de Recherche pour Le Développement (IRD - França). O trabalho de campo também contou com o apoio logístico de transporte do Exército, do Instituto de Desenvolvimento Agropecuário do Estado da Amazonas (IDAM) e do Instituto Nacional para Pesquisa Amazônica (INPA).

\section{BIBLIOGRAFIA}

ARNON, I. Modernization of Agriculture in Developing Countries. Chichester, Wiley, 1981

ATKINSON, A. Principles of Politcal Ecology. Belhaven: London, 1991.

BASSETT, T.J. e ZIMMERER, K.S. Cultural Ecology. In: Gaile, G.L. e C.J., Willmott (eds.) Geography in America at the Daen of the $21^{\circ}$ Century., p. 91-111. New York: Oxford University Press, 2003.
BICALHO, A. M. S. M. e HOEFLE, S. W. Environment Perception and Sustainable Development in the Atlantic Forest of Southeast Brazil. Monograph 6, pp-1-35. Montreal: Union Géographique Internacional/ Université de Montreal, 2002

CASTREE, N. Geographies of Nature in the Making. In: Anderson, K. , Domosh, M. , Pile, S. , Thrift, N. (eds). Handbook of Cultural Geograpby, p- 168-183. London, Sage, 2003.

CLAVAL, P. Geografia Cultural. Florinópolis: UFSC, 1999.

CLIFFORD, J. Introduction: Partial Truths. In: Clifford, J. e Marcus G. E. (eds), Writing Culture. P-1-26. Berkeley:

University of California Press, 1986.

COSGROVE, D. Landscape and the European Sense of Sight - Eyeing Nature. In: Anderson, K. , Domosh, M., Pile, S.

Thrift, N. (eds), Handbook of Cultural Geograpby. P- 249-268. London: Sage, 2003.

FOSTER, G. M. Traditional Societies and Technological Change. New York: Harper e Row, 1972 (1964).

GEERTZ, C. Interpretation of Cultures. New York: Basic Books, 1973.

HOEFLE, S. W. Continuity and Change in the Northeastern Sertão od Brazil. Tese de doutorado, Institute of Social Anthropology, University of Oxford, 1983.

. O Sertanejo e o Bichos: Cognição Ambiental na Zona Semi-Árida Nordestina. Revista da Antropologia 33, p. 47-74, 1990.

. Mundividências Encantadas e Desencantadas no Sertão do Nordeste Brasileiro. Análise Social 32 (1): p - 189 213, 1997. 
Pesquisando Percepção Ambiental na Mata Atlântica Fluminense: Uma abordagem Qualitativa Sistemática. III Fórum de Investigação Qualitativa: 1-25. Juiz de Fora, UFJF, 2002.

HUNTER, G. Modernizing Peasant Societies. London: Oxford University Press, 1969.

LÉVI-STRAUSS, C. The Raw and the Cookes: Introduction to a Science of Mythology. New York: Harper, 1972 (1969).
LONG, N. Sociology od Development. London: Metheun, 1982. MALONEY, C (ed) The Evil Eye. New York: Columbia University Press, 1976.

MARX, K. Capital. Chicago: Great Books, 1952 (1869).

MERCHANT, C. Radical Ecology. $2^{a}$ edição. London: Routledge, 2005.

\section{ABSTRACT}

THE RELATIONSHIP BETWEEN FARMING SYSTEMS, ENVIRONMENTAL ETHICS AND RELIGIOUS WORLDVIEWS IS ANALYSED IN THE CENTRAL AMAZON COMPARING AND CONTRASTING MARXIST/STRUCTURALIST, SPIRITUAL ECOLOGIST AND POLITICAL ECOLOGIST MODELS. ENCHANTED VIEWS OF NATURE ARE COMMON AMONG AMAZONIAN PEASANTS AND REFLECT CENTURIES OF AMERINDIAN-EUROPEAN CULTURAL-ETHNIC FUSION. A RICH LORE OF FOREST AND RIVER SPIRITUAL ENTITIES EXISTS SO THAT THE QUESTION ARISES AS TO WHETHER ACCORDING TO A SPIRITUAL ECOLOGY APPROACH RECIPROCAL RELATIONSHIPS BETWEEN SPIRITS AND HUMANS PROVIDE AN IDEOLOGICAL SHIELD AGAINST PROBLEMS WITH DEFORESTATION AND SOCIAL INEQUITY PRESENT IN MODERN FARMING SYSTEMS. MARXIST/STRUCTURALIST MODELS IN COUNTERPOINT HOLD THAT ENCHANTED WORLDVIEWS ARE MERE IDEOLOGICAL EPI-PHENOMENA WHICH ARE SWEPT AWAY DURING THE PROCESS OF RURAL CAPITALISATION/MODERNISATION, MAINLY BECAUSE UNPREDICTABLE NATURAL PHENOMENA ARE TAMED WITH TECHNOLOGY. NON-CAPITALISED AND CAPITALISED FARMING SYSTEMS PRESENT IN THE AMAZON ARE ANALYSED WITH REGARD TO THE BELIEF IN FOREST SPIRITS AND THE EVIL EYE, TO THE DEGREE OF FLORAL AND FAUNAL ELIMINATION/SUBSTITUTION AND TO SOCIAL EQUITY. A HOLISTIC POLITICAL ECOLOGY APPROACH TO ENVIRONMENTAL ETHICS AND RURAL TRANSFORMATION IS OFFERED AS AN ALTERNATIVE TO TYPICAL DETERMINISTIC INTERPRETATIONS OF RURAL MODERNISATION AND WORLDVIEW DISENCHANTMENT.

KEY WORDS: ENVIRONMENTAL ETHICS, CULTURAL LANDSCAPE, AMAZON. 